\title{
PERANAN POSYANDU DALAM MENINGKATKAN STATUS GIZI BALITA DI WILAYAH KERJA PUSKESMAS MADISING NA MARIO KOTA PAREPARE
}

\section{The Role of Posyandu in Increasing Nutrition Status in the Working Areas of Health Center Madising Na Mario City of Parepare}

\author{
Aldita, Muhammad Siri Dangnga, Erna Magga \\ Program Studi Kesehatan Masyarakat Fakultas Ilmu Kesehatan Universitas Muhammadiyah \\ Parepare \\ ( alditaangeraini0@gmail.com 082292273824 )
}

\begin{abstract}
ABSTRAK
Balita adalah individu atau sekelompok individu dari suatu penduduk yang berada di dalam rentang usia tertentu, pada masa balita perkembangan kemampuan berbahasa, kreativitas, kesadaran sosial, dan inteligensia berjalan sangat cepat. Faktor gizi sangat berperan sekali dalam pertumbuhan dan perkembangan anak selanjutnya. Tujuan penelitian ini untuk mengetahui kegiatan pemberian imunisasi, pemberian makanan tambahan, penimbangan berat badan dan penyuluhan dalam meningkatkan status gizi balita di wilayah kerja Puskesmas Madising Na Mario Kota Parepare, pada bulan Mei-Juni 2018. Populasi penelitian ini adalah seluruh ibu yang memiliki balita di Puskesmas Madising Na Mario Kota Parepare dengan metode pengambilan sampel yaitu Simple Random Sampling dengan jumlah 87 sampel. Metode yang digunakan dalam penelitian ini adalah metode deskriptif yang bertujuan untuk mengetahui suatu gambaran terhadap posyandu dalam meningkatkan status gizi balita. Hasil penelitian menunjukkan bahwa pemberian imunisasi lengkap sebanyak 87 responden (100\%), pemberian makanan tambahan baik sebanyak 85 responden $(97,7 \%)$, penimbangan berat badan akurat sebanyak 80 responden $(92 \%)$, dan penyuluhan baik sebanyak 82 responden $(94,3 \%)$. Diharapakan ibu balita meningkatkan kelengkapan imunisasi, pemberian makanan tambahan, penimbangan berat badan, penyuluhan guna meningkatkan status gizi balita.
\end{abstract}

Kata kunci: Imunisasi, pemberian makanan tambahan, penimbangan berat badan, penyuluhan, peningkatan status gizi balita

\footnotetext{
ABSTRACT

Toddlers are individuals or a group of individuals from a population within a certain age range, in the toddler age the development of language skills, creativity, social awareness, and intelligence runs very fast. Nutritional factors are very instrumental in the growth and development of the next child. The purpose of this study was to determine the activities of immunization, supplementary feeding, weighing and counseling in improving the nutritional status of children in the working area of Madising Na Mario Health Center in Parepare City, May-June 2018. The population of this study were all mothers who had children under five Madising Na Mario Health Center in Parepare City with a sampling method, Simple Random Sampling with 87 samples. The method used in this research is descriptive method which aims to find out an illustration of posyandu in improving the nutritional status of children. The results showed that the provision of complete immunization was 87 respondents (100\%), supplementary feeding was as good as 85 respondents (97.7\%), accurate weighing of 80 respondents (92\%), and good counseling as many as 82 respondents $(94,3 \%)$. It is expected that toddler mothers improve the completeness of immunization, supplementary feeding, weighing the body weight, counseling to improve the nutritional status of children.
} 
Keywords: Immunization, supplementary feeding, weighing of body weight, counseling, improvingnutritional status of children under five 


\section{PENDAHULUAN}

Kualitas Sumber Daya Manusia (SDM) merupakan syarat mutlak menuju pembangunan di segala bidang. Periode penting dalam tumbuh kembang anak adalah masa balita, karena pada masa ini pertumbuhan dasar yang akan mempengaruhi dan menentukan perkembangan anak selanjutnya. Balita adalah individu atau sekelompok individu dari suatu penduduk yang berada dalam rentang usia tertentu. Usia balita dapat dikelompokan menjadi tiga golongan yaitu golongan usia bayi (0-2 tahun), golongan batita (2-3 tahun) dan golongan pra sekolah (> 3-5 tahun). ${ }^{1}$

Pada masa balita perkembangan kemampuan berbahasa, kreativitas, kesadaran sosial, dan inteligensia berjalan sangat cepat. Faktor gizi sangat berperan sekali dalam pertumbuhan dan perkembangan anak selanjutnya. Status gizi merupakan salah satu faktor yang sangat berpengaruh pada kualitas SDM terutama yang terkait dengan kecerdasan, produktivitas dan kreativitas. ${ }^{1}$

Masalah kekurangan gizi pada anak balita di Indonesia khusus di Sulawesi Selatan merupakan salah satu masalah kesehatan yang perlu mendapat perhatian yang serius. Sulawesi Selatan sudah dikenal sebagai Lumbung Pangan khususnya untuk kawasan Indonesia Timur, namun di daerah ini rawan terhadap gizi kurang dan gizi buruk. Berdasarkan hasil Riset Kesehatan Dasar (RisKesDas) Tahun 2013, Sulsel termasuk dalam sepuluh provinsi yang terbanyak angka gizi kurang $(19,0 \%)$ dan gizi buruk (6.6\%), lebih tinggi dari angka nasional yang hanya mencapai $5.7 \%$ dan 13.9\%. Proporsi balita yang mengalami gangguan pertumbuhan tinggi badan adalah pendek sebanyak $19.2 \%$ dan sangat pendek $18.0 \%$. Proporsi balita yang kurus maupun sangat kurus masing-masing $6.8 \%$ dan $5.3 \% .^{2}$

Berdasarkan data dari Departemen Kesehatan RI tahun 2011, suatu masyarakat disebut tidak mempunyai masalah kesehatan bila hanya ada $2,0 \%$ balita mempunyai status gizi kurang dan $0,5 \%$ balita mempunyai status gizi buruk. ${ }^{3}$ Ada tidaknya masalah gizi anak disuatu daerah tidak jauh dari kontribusi peranan kader posyandu. Secara teknis, tugas atau peran kader yang terkait dengan gizi adalah melakukan pendataan balita, melakukan penimbangan serta mencatatnya dalam Kartu Menuju Sehat (KMS), memberikan makanan tambahan, mendistribusikan vitamin A, melakukan penyuluhan gizi serta kunjungan kerumah ibu yang memiliki balita. Kader diharapkan berperan aktif dan mampu menjadi pendorong, motivator dan penyuluh masyarakat. ${ }^{4}$

Peranan kader sangat penting karena kader bertanggung jawab dalam pelaksanaan program posyandu. Bila kader tidak aktif maka pelaksanaan posyandu juga akan menjadi tidak lancar dan akibatnya status gizi balita tidak dapat dideteksi secara dini dengan jelas. ${ }^{5}$ 
Kader merupakan titik sentral dalam pelaksanaan kegiatan posyandu. Keikutsertaan dan keaktifannya diharapkan mampu menggerakkan partisipasi masyarakat. Namun, keberadaan kader relatif labil karena partisipasinya bersifat sukarela sehingga tidak ada jaminan untuk tetap menjalankan fungsinya dengan baik seperti yang diharapkan. Jika ada kepentingan keluarga atau kepentingan lainnya maka posyandu akan ditinggalkan. ${ }^{6}$

Puskesmas Madising Na Mario terletak di tengah Kota Parepare dan merupakan satu dari enam Puskesmas yang ada di Kota Parepare yang dikembangkan menjadi Safe Community dan Brigade Siaga Bencana sejak 9 Januari 2003.

Puskesmas Madising Na Mario memiliki kegiatan posyandu untuk menurunkan angka kesakitan dan kematian yang diderita oleh balita. Penyakit yang dapat dicegah dengan imunisasi seperti difteri, tetanus, batuk rejan (pertusis), campak, polio dan tuberkulosis. Kegiatan perbaikan gizi untuk meningkatkan status gizi pada ibu hamil, ibu menyusui, bayi dan balita baik secara lintas program maupun lintas sektoral antara lain pemberian makanan tambahan, kapsul vitamin A, kapsul $\mathrm{Fe}$ dan tumbuh kembang anak. ${ }^{7}$

Dari data yang diperoleh pada bulan Maret 2018 Puskesmas Madising Na Mario terdapat balita yang memiliki gizi kurang sebanyak 26 anak, dan balita yang memiliki gizi lebih sebanyak 13 orang, maka dari itu peneliti tertarik menemukan alasan meneliti di Puskesmas Madising Na Mario Kota
Parepare dengan judul "Peranan Posyandu dalam Meningkatkan Status Gizi Balita di Wilayah Kerja Puskesmas Madising $\mathrm{Na}$ Mario Kota Parepare".

\section{BAHAN DAN METODE}

Metode penelitian yang digunakan adalah penelitian deskriptif, yaitu suatu gambaran terhadap posyandu dalam meningkatkan status gizi balita. Lokasi penelitian ini dilakukan di Wilayah kerja Puskesmas Madising $\mathrm{Na}$ Mario Kota Parepare. Adapun waktu penelitian pada bulan April-Juli 2018. Instrumen dalam penelitian ini adalah menggunakan timbangan, microtoise dan kuesioner. Populasi pada penelitian merupakan seluruh ibu yang memiliki balita di Puskesmas Madising Na Mario. Adapun teknik pengambilan sampel dalam penelitian ini dilakukan melalui teknik sistem Simple Random Sampling, dengan sampel berjumlah 87 balita. Analisis data univariat menggunakan teknik deskriptif yaitu bertujuan untuk menggambarkan distribusi frekuensi dari masing-masing variabel yang diteliti baik variabel independen maupun dependen.

\section{HASIL}

Analisis karakteristik responden ini menggunakan distribusi tabel dengan data yang diperoleh dari kuesioner yang berdasarkan umur, berat badan, tinggi badan, status gizi di Wilayah kerja Puskesmas Madising Na Mario Kota Parepare. Tabel 1 dapat kita lihat bahwa umur rata-rata $>45$ 
bulan $35,6 \%$, berat badan $12-15 \mathrm{~kg} 63,2 \%$, tinggi badan $91-100 \mathrm{~cm} 51,7 \%$, dengan status gizi normal sebanyak $70(80,5 \%)$. Untuk pemberian imunisasi didapatkan hasil pemberian imunisasi lengkap sebanyak 87 responden $(100 \%)$ dan tidak ada responden dengan imunisasi yang tidak lengkap (tertera pada Tabel 2).

Tabel 3 menunjukkan bahwa dari 8 posyandu sebanyak 87 balita pemberian makanan tambahan baik sebanyak 85 responden $(97,7 \%)$ dan pemberian makanan tambahan tidak baik sebanyak 2 (2,3\%). Sedangkan hasil penimbangan berat badan yang baik sebanyak 80 responden $(92,0 \%)$ dan penimbangan berat badan yang tidak baik sebanyak 7 (8,0\%), seperti yang tertera pada Tabel 4. Untuk Tabel 5 menggambarkan bahwa dari 8 poyandu yang dilakukan penyuuluhan didapatkan hasil penyuluhan baik sebanyak 82 responden $(94,3 \%)$ dan penyuluhan tidak baik sebanyak $5(5,7 \%)$.

\section{PEMBAHASAN}

Status gizi adalah ukuran keberhasilan dalam pemenuhan nutrisi untuk anak yang diindikasikan oleh berat badan dan tinggi badan. Status gizi juga didefinisikan sebagai status kesehatan yang dihasilkan oleh keseimbangan antara kebutuhan dan masukan nutrient.

Imunisasi merupakan pemberian kekebalan pada bayi dan anak tehadap berbagai penyakit, sehingga bayi dan anak tumbuh dalam keadaan sehat. ${ }^{8}$ Pemberian imunisasi merupakan tindakan pencegahan agar tubuh tidak terjangkit penyakit infeksi tertentu seperti tetanus, batuk rejan (pertusis), campak (meales), polio dan tuberkulosis atau seandainya terkenapun, tidak memberikan akibat yang fatal bagi tubuh. Penyakit infeksi atau menular dapat dicegah dengan imunisasi. ${ }^{9}$

Berdasarkan pemberian imunisasi, dari 87 responden hasil penelitian yang di lakukan di Puskesmas Madising Na Mario Kota Parepare, diperoleh hasil yaitu pemberian imunisasi lengkap sebanyak 87 $(100 \%)$ responden sedangkan tidak lengkap sebanyak $0(0 \%)$. Hal ini menunjukkan bahwa posyandu sangat berperan sangat baik dalam peningkatan status gizi pada balita. Peranan kader pada kegiatan posyandu Puskesmas Madising Na Mario sudah dapat dikatakan baik karena kader sangat bertanggung jawab dalam pelaksanaan program posyandu. Selain itu posyandu berjalan dengan baik karena kader sebelum membuka posyandu kader posyandu terlebih dahulu melakukan beberapa persiapan seperti penyiapan tempat, pemeriksaan alat penimbangan apakah masih layak digunakan atau tidak, menyiapkan buku registrer posyandu dan menyiapkan pemberian makanan tambahan. Hal ini sejalan dari hasil penelitian Ningrum (2008) bahwa survai menunjukkan anak dengan ibu yang terlibat aktif dalam pengambilan keputusan di rumah tangga telah mendapatkan imunisasi lengkap (Hepatitis, BCG, Campak, DPT, Polio) lebih banyak di banding pada anak yang ibunya 
tidak terlibat dalam pengambilan keputusan rumah tangga. ${ }^{10}$

Makanan tambahan adalah makanan bergizi sebagai tambahan selain makanan utama bagi kelompok sasaran guna memenuhi kebutuhan gizi. Untuk mengatasi kekurangan gizi yang terjadi pada kelompok usia balita perlu diselenggarakan pemberian makanan tambahan pemulihan. Bagi anak usia 6-59 bulan dimaksudkan sebagai tambahan, bukan sebagai tambahan, bukan sebagai pengganti makanan utama seharihari. Pemberian makanan tambahan pemulihan dimaksud berbasis bahan makanan lokal dengan menu khas daerah yang disesuaikan dengan kondisi setempat.

Berdasarkan pemberian makanan tambahan, dari 87 responden hasil penelitian yang di lakukan di Puskesmas Madising $\mathrm{Na}$ Mario Kota Parepare, diperoleh hasil yaitu pemberian makanan tambahan baik sebanyak $85(97,7 \%)$ responden sedangkan pemberian makanan tambahan tidak baik sebanyak $2(2,3 \%)$ reponden. Hal ini menunjukkan bahwa posyandu sangat berperan baik terhadap pemberian makanan tambahan terhadap balita, karena dari 87 responden rata-rata balita menerima pemberian makanan tambahan. Menurut Fauziah (2009) dalam penelitiannya menyebutkan bahwa anak balita usia 1-5 tahun bersifat konsumen pasif, artinya makanan yang dikonsumsi tergantung pada apa yang disediakan oleh ibu, sehingga keterampilan ibu dalam rencana pemberian makanan juga perlu di perhatikan. ${ }^{11}$
Penimbangan bayi dan balita dimaksud untuk memantau pertumbuhannya setiap bulan. Penimbangan bayi dan balita dilakukan setiap bulan mulai umur 1 bulan sampai 5 tahun di posyandu. Setelah bayi dan balita di timbang, catat hasil penimbangan di buku KMS (kartu menuju sehat), maka akan dilihat berat badannya naik atau tidak naik (lihat perkembangannya).

Berdasarkan penimbangan berat badan yang dilakukan Puskesmas Madising $\mathrm{Na}$ Mario Kota Parepare pada balita dikatakan baik, hal ini membuktikan dari hasil penelitian 80 responden yang menimbang anaknya di posyandu. Hal ini menunjukkan bahwa peranan posyandu sudah dikatakan baik karena 80 responden telah melakukan penimbangan terhadap anaknya. Hal ini tidak lepas dari faktor pengetahuan ibu balita. Hal ini sejalan dengan penelitian Riska yang mengatakan bahwa ibu yang memiliki pengetahuan baik tentu akan berpartisipasi menimbang balitanya ke posyandu. Faktor lain yang mempengaruhi ibu adalah adanya dukungan keluarga yang dapat memotivasi ibu sehingga ibu aktif menimbang balitanya ke posyandu. Sikap positif ini merupakan aset yang dapat digunakan oleh pemerintah setempat dalam upaya peningkatan status gizi balita, sebab sikap yang baik memiliki kontribusi yang cukup signifikan terhadap perilaku. Hal ini sejalan dengan penelitian yang dilakukan oleh Reihana (2012) yaitu dukungan keluarga dengan partisipasi ibu untuk menimbang anaknya ke posyandu. 
Penyuluhan kesehatan adalah penambahan pengetahuan dan kemampuan seseorang melalui teknik praktik belajar atau instruksi dengan tujuan mengubah atau mempengaruhi prilaku manusia baik secara individu, kelompok maupun masyarakat untuk meningkatkan kesadaran akan nilai kesehatan sehingga dengan sadar mau mengubah perilakunya menjadi perilaku hidup sehat.

Berdasarkan penyuluhan yang dilakukan 8 posyandu Puskesmas Madising $\mathrm{Na}$ Mario Kota Parepare pada balita dikatakan baik, hal ini membuktikan dari hasil penelitian 82 responden yang mengikuti penyuluhan di posyandu dikatakan baik. Hal ini menunjukkan bahwa peran posyandu sangat berperan karena dalam dilaksanakannya penyuluhan masyarakat bisa tahu pentingnya menjaga kesehatan anak balita, mengatur makanan yang diberikannya dan membawa anaknya ke posyandu, sehingga ibu balita bisa mengetahui perkembangan dan pertumbuhan anaknya. Penelitian ini sejalan dengan penelitian Intan (2012) yaitu dukungan tokoh masyarakat dengan perilaku kunjungan ibu balita ke posyandu. ${ }^{13}$

\section{KESIMPULAN DAN SARAN}

Berdasarkan hasil penelitian dari peranan posyandu dalam meningkatkan status gizi balita di wilayah kerja puskesmas madising na mario kota parepare. Dapat disimpulkan bahwa kegiatan pemberian imunisasi di Puskesmas Madising Na Mario Kota Parepare diusahakan lengkap sebanyak 87 responden (100\%), kegiatan pemberian makanan tambahan di Puskesmas Madising $\mathrm{Na}$ Mario Kota Parepare diusahakan baik sebanyak 85 responden $(97,7 \%)$ dan tidak baik sebanyak 2 responden (2,3\%), kegiatan penimbangan berat badan di Puskesmas Madising $\mathrm{Na}$ Mario Kota Parepare diusahakan akurat sebanyak 80 responden $(92,0 \%)$ dan tidak akurat sebanyak 7 responden $(8,0 \%)$, kegiatan penyuluhan di Puskesmas Madising Na Mario Kota Parepare diusahakan baik sebanyak 82 responden $(94,3 \%)$ dan tidak baik sebanyak 5 responden (5,7\%). Berdasarkan kesimpulan maka penulis menyarankan sebaiknya ibu balita lebih meningkatkan kelengkapan imunisasi pada balita guna meningkatkan status gizi pada balita, sebaiknya ibu balita lebih meningkatkan makanan tambahan yang diberikan pada balita guna meningkatkan status gizi pada balita, sebaiknya ibu balita lebih meningkatkan penimbangan berat badan pada balita guna meningkatkan status gizi pada balita, sebaiknya ibu balita lebih meningkatkan penyuluhan pada balita guna meningkatkan status gizi pada balita.

\section{DAFTAR PUSTAKA}

1. Adriani, M. dan Wirjatmadi, B. Pengantar Gizi Masyarakat. Jakarta: Kencana Prenada Media Group; 2012. 
2. Kemenkes RI. Riskesdas dalam angka Provinsi Sulawesi Selatan. Jakarta Kemenkes RI; 2013.

3. Depkes RI. Profil Kesehatan Indonesia 2010. Jakarta: Kementrian Kesehatan Republik Indnesia; . 2011.

4. Ismarawanti, D. N. Kader Posyandu : Peranan Dan Tantangan Pemberdayaannya Dalam Usaha Peningkatan Gizi Anak Di Indonesia. Jurnal Manajemen Pelayanan Kesehatan. 2010; 13(04) : 169-173. [Diakses tanggal 10 Maret 2018]. Available at: http://download.portalgaruda.org/ article.

5. Isaura, V. Faktor - Faktor Yang Berhubungan Dengan Kinerja Kader Posyandu Di Wilayah Kerja Puskesmas Tarusan Kecamatan Koto XI Tarusan Kabupaten Pesisir Selatan. Padang : Universitas Andalas. 2011:2. [Diakses tanggal 15 Maret 2018]. Available at :http://repository.unand.ac.id/175 32/1/FAKTOR.pdf.

6. Syafeih, A. Faktor - Faktor Yang Berhubungan Dengan Partisipasi Kader Dalam Kegiatan Gizi Posyandu Di Kelurahan Rengas Kecamatan Ciputat Timur Kota Tangerang Selatan. Jakarta : Universitas Islam Negeri Syarif Hidayatullah. 2010: 23. [Diakses tanggal 16 Maret 2018]. Available at: http://repository.uinjkt.ac.id.
7. Profil Puskesmas Madising Na Mario, 2017.

8. Hidayat A. Pengantar Ilmu Kesehatan Anak, Jakarta: Salemba Medika; 2008.

9. Achmadi UF. Imunisasi: mengapa perlu? Jakarta: Penerbit Buku Kompas; 2006.

10. Nigrum, E.P,. Faktor-faktor Yang Mempengaruhi Kelengkapan Imunisasi Dasar Pada Bayi Di Puskesmas Banyudono Kabupaten Boyolali. Berita Ilmu Keperawatan ISSN. 2008: 19792697, Vol, I.

11. Fauzih, D. Pola Konsumsi Pangan dan Status Gizi Anak Balita yang Tinggal di Daerah Rawan Pangan di Kabupaten Banjar Negara. Skripsi. Bogor: Institut Teknologi Bandung; 2009.

12. Reihana, Dkk. Jurnal Kedokteran Yarsi. 2012; 20 (3): 143-157.

13. Suhartini, R., Haniarti, H., \& Majid, M. (2018). Hubungan Status Gizi Dengan Perkembangan Motorik Kasar Anak Umur 1-3 Tahun Di Posyandu Bunga Cengkeh Desa Puncak Harapan Kecamatan MaiwA. Jurnal Ilmiah MANUSIA DAN KESEHATAN, 1(3), 177-188.

14. Usman, u., \& Rusman, a. D. P. (2018). Faktor Yang Berhubungan Dengan Pemanfaatan Antenatal Care Di Puskesmas Madising Na Mario Kota Parepare. Jurnal Ilmiah Manusia dan Kesehatan, 1(1), 1-15. 


\section{LAMPIRAN}

Tabel 1. Distribusi responden berdasarkan umur

\begin{tabular}{ccc}
\hline Umur & Frekuensi (n) & Persentase $(\boldsymbol{\%})$ \\
\hline $15-25$ bulan & 12 & 13,8 \\
$26-35$ bulan & 18 & 20,7 \\
$36-45$ bulan & 26 & 29,9 \\
$>45$ & 31 & 35,6 \\
\hline Total & 87 & 100,0 \\
\hline
\end{tabular}

Tabel 2. Distribusi responden berdasarkan berat badan

\begin{tabular}{ccc}
\hline BB & Frekuensi (n) & Persentase (\%) \\
\hline $8-11$ & 22 & 25,3 \\
$12-15$ & 55 & 63,2 \\
$>16$ & 10 & 11,5 \\
\hline Total & 87 & 100,0 \\
\hline
\end{tabular}

Tabel 3. Distribusi responden berdasarkan tinggi badan

\begin{tabular}{ccc}
\hline TB & Frekuensi (n) & Persentase (\%) \\
\hline $70-80$ & 13 & 14,9 \\
$81-90$ & 24 & 27,6 \\
$91-100$ & 45 & 51,7 \\
$>100$ & 5 & 5,7 \\
\hline Total & 87 & 100,0 \\
\hline
\end{tabular}

Tabel 4. Distribusi responden berdasarkan status gizi

\begin{tabular}{ccc}
\hline Status gizi & Frekuensi (n) & Persentase (\%) \\
\hline Normal & 70 & 80,5 \\
Kurang & 17 & 19,5 \\
\hline Total & 87 & 100,0 \\
\hline
\end{tabular}

Tabel 5. Distribusi responden berdasarkan pemberian imunisasi di Puskesmas Madising Na Mario Kota Parepare

\begin{tabular}{ccc}
\hline Pemberian imunisasi & Frekuensi (n) & Persentase (\%) \\
\hline Lengkap & 87 & 100,0 \\
Tidak lengkap & 0 & 0 \\
\hline Total & 87 & 100,0 \\
\hline
\end{tabular}

Tabel 6. Distribusi responden berdasarkan pemberian makanan tambahan di Puskesmas Madising Na Mario Kota Parepare

\begin{tabular}{ccc}
\hline $\begin{array}{c}\text { Pemberian makanan } \\
\text { tambahan }\end{array}$ & Frekuensi (n) & Persentase (\%) \\
\hline Baik & 85 & 97,7 \\
Tidak baik & 2 & 2,3 \\
\hline Total & 87 & 100,0 \\
\hline
\end{tabular}


Tabel 7. Distribusi responden berdasarkan penimbangan berat badan di Puskesmas Madising Na Mario Kota Parepare

\begin{tabular}{ccc}
\hline $\begin{array}{c}\text { Penimbangan berat } \\
\text { badan }\end{array}$ & Frekuensi (n) & Persentase (\%) \\
\hline Akurat & 80 & 92,0 \\
Tidak akurat & 7 & 8,0 \\
\hline Total & 87 & 100,0 \\
\hline
\end{tabular}

Tabel 8. Distribusi responden berdasarkan penyuluhan di Puskesmas Madising Na Mario Kota Parepare

\begin{tabular}{ccc}
\hline Penyuluhan & Frekuensi (n) & Persentase (\%) \\
\hline Baik & 82 & 94,3 \\
Tidak baik & 5 & 5,7 \\
\hline Total & 87 & 100,0 \\
\hline
\end{tabular}

